\title{
Plant growth promoter collection of Gluconacetobacter diazotrophicus from the northern coast of Peru
}

\author{
Johnnel J. Paredes-Villanueva1; J.L. Del Rosario²; Mirtha M. Urcia-Pulido'; Julio C. \\ Zavaleta-Armas ${ }^{1, *}$ \\ 1 Laboratorio de Análisis de Suelos y Foliares, Universidad Nacional de Trujillo. Av. Juan Pablo II s/n. Ciudad \\ Universitaria, Trujillo, Peru. \\ 2 Laboratorio de Biología Molecular, Universidad Nacional de Trujillo. Av. Juan Pablo II s/n. Ciudad Universitaria, \\ Trujillo, Peru.
}

Received July 1st, 2019. Accepted January 25, 2020.

\begin{abstract}
The application of plant growth-promoting bacteria (PGPB) represents a friendly alternative to the environment, in contrast to the use of chemical fertilizers. Endophytic bacteria can develop inside the plant tissues and directly benefit the plant. Gluconacetobacter diazotrophicus is a versatile bacterium that has been isolated from different plants and possesses different physiological properties that would serve to improve plant development. In this research, five cultures of $G$. diazotrophicus were isolated from sugarcane samples from the northern coast of Peru. The isolates showed the ability to solubilize phosphates and zinc, produce IAA, and resist salt stress $(\mathrm{NaCl} 1 \%)$. Antagonism evaluations showed that they can inhibit up to $75 \%, 57 \%, 40 \%, 49 \%$ and $17 \%$ of the development of Fusarium sp., Alternaria sp., Roselinia sp., Lasiodiplodia sp., and Sclerotinia sp., respectively. Inoculation plant experiments were developed by inoculating individual and bacteria mixture. All treatments showed plant growth promotion in sugarcane, but the mixture of $G$. diazotrophicus LASFB 1573, Klebsiella sp. LASFBP 086 and Enterobacter sp. LASFB 009 increased up to $84 \%$ and $89 \%$ in fresh and dry plant weight, respectively. The results show that the isolates have a high potential as PGPB and could be used later to improve the development of different crops.
\end{abstract}

Keywords: bacteria; biofertilizer; endophytic; biological nitrogen fixation; plant growth promotion bacteria.

\section{Introduction}

The use of PGPB is an environment friendly, low-cost alternative that is being implemented in a variety of crops. Nevertheless, the implementation of this technology is very limited, despite being known for decades. Consequently, the use of microorganisms as biofertilizers is not a widespread practice. This is due to the particular use conditions of each microbial group that can be considered as PGPB (Vejan et al., 2016; Tabassum et al., 2017).

The use of living organisms that interact with plants favors the development through direct and indirect mechanisms, which have been described by different researchers (Brader et al., 2014; de Souza et al., 2015). These mechanisms are based on the ability to produce phytohormones and siderophores, and to solubilize phosphates or other important nutrients for the plant. Indirect mechanisms are related to the production of antimicrobial compounds that prevent the attack of pathogens, induce systemic resistance on the plant, and improve soil conditions (Bishnoi, 2015). Therefore, applying biofertilizers would reduce the use of chemical products that have generated a severe environmental impact (Bouraoui and Grizzetti, 2013).

Gluconacetobacter diazotrophicus is a very efficient nitrogen-fixing bacterium with which many interaction studies have been carried out with several non-legume plants (Oliveira et al., 2009; Luna et al., 2012; Chawla et al., 2014). The flexibility in the interactions between this bacterium and different vegetables makes it a very attractive alternative as a biofertilizer. $\boldsymbol{G}$. diazotrophicus has exhibited the ability to

How to cite this article:

Paredes-Villanueva, J.; Del Rosario, J.L.; Urcia Pulido, M.M.; Zavaleta-Armas, J.C. 2020. Plant growth promoter collection of Gluconacetobacter diazotrophicus from northern coast of Peru. Scientia Agropecuaria 11(1): 15-21. 
colonize different plants and can be inserted in different tissues. It was isolated initially in sugarcane crops, but it has also been isolated in tomato (Luna et al., 2012), rice (Jha et al., 2009), corn (Tian et al., 2009) and a variety of tropical and subtropical plants (Madhaiyan et al., 2004). In the same way, this bacterium has been detected in plant organs such as stems, leaves, fruits, and seeds (Botta et al., 2013; Santoyo et al., 2016).

The ability to infect the internal tissues of the root, as well as other organs, allows the bacteria to generate a direct benefit to the host, and to avoid competition with soil and rhizosphere microorganisms. It has been described the bacterial mechanisms to be able to colonize plant tissues, and their mobilization through the vascular tissues of the plant to reach other organs (Gaiero et al., 2013). This bacterium has shown favorable results for plant development under different conditions, either inoculated individually or in consortium with other bacteria (Hernández-Escareño et al., 2015). There are also other species within the family and the genus that possibly have similar promoter properties to $G$. diazotrophicus (Muthukumarasamy et al., 2005; Mehnaz et al., 2006). The objective of this work was to isolate native $G$. diazotrophicus from sugarcane located in different regions of northern Peru, as well as test their potential as a biofertilizer.

\section{Materials and methods}

\section{Isolation and phenotypic characterization}

Samples were collected from the northern coast of Peru, in Ancash, La Libertad, Lambayeque and Piura Regions. Each plant sample was subdivided into leaf, stem, and root. $10 \mathrm{~g}$ of each subsample was taken and disinfected with $70 \%$ ethanol, then with a $2 \%$ sodium hypochlorite solution for $5 \mathrm{~min}$, and consecutive washes with sterile distilled water. Then the samples were macerated and diluted up to $10^{-3}$ in a sterile solution of $\mathrm{NaCl}(0.8 \%)$. $100 \mu \mathrm{l}$ of each dilution was inoculated in the semisolid LGI-P medium. Incubation was carried out for 5 to 7 days at $30{ }^{\circ} \mathrm{C}$. Then, it was plated on solid LGI-P medium and incubated at $30^{\circ} \mathrm{C}$ for 5 to 7 days (Baldani et al., 2014).

The phenotypic characterization, catalase, indole, nitrate reduction, and urease were tested. The selected cultures were cultivated in 10\% Sucrose Potato Agar (SPA) to observe the dark brown colored colonies and the development capability in LGI-P with $30 \%$ sucrose was evaluated (Madhaiyan et al., 2004; Mehnaz et al., 2006).

\section{Amplification of the 16S rRNA gene by PCR} and sequencing

The selected isolates were cultured in DYGS medium at $30^{\circ} \mathrm{C}$ for 24 hours. Thermal lysis was performed to obtain bacterial DNA. 10 $\mu \mathrm{L}$ of culture was suspended in $100 \mu \mathrm{L}$ of ultrapure water, and after lysis, the DNA was kept at $-20^{\circ} \mathrm{C}$ until its use (Rivas et al., 2001). For the amplification of the 16S rRNA gene, Master Mix 2X (Promega) was used according to the manufacturer's instructions. The primers 27F AGAGTTTGATCCTGGCTCAG-3') and 1492r (5'-GGTTACCTTGTTACGACTT-3') were used at a final concentration of $0.5 \mu \mathrm{M}$ and 1 $\mu \mathrm{L}$ of the sample was added. PCR was performed in a MasterCycler Eppendorf thermal cycler with a 3 min PCR program at $95^{\circ} \mathrm{C}$, followed by 30 cycles of $95^{\circ} \mathrm{C}$ for 30 $\mathrm{s}, 54^{\circ} \mathrm{C}$ for $30 \mathrm{~s}$ and $72^{\circ} \mathrm{C}$ for $90 \mathrm{~s}$, with a final extension of $10 \mathrm{~min}$ at $72{ }^{\circ} \mathrm{C}$. PCR products were then sent to sequence to Macrogen (Korea), the sequences were ensembled and analyzed using the BLAST tool (http://www.ncbi.nlm.nih.gov/BLAST), to compare the homology of the nucleotide sequences. Related sequences were obtained, and an alignment was made with ClustalW using the software MEGA7. The phylogenetic analysis was done using the Neighbor-Joining method and the Kimura two-parameter substitution model with 1000 Bootstrap replications (Khan et al., 2014).

\section{Multiplex PCR assay for G. diazotrophicus} identification

The multiplex PCR technique was developed according to Madhaiyan et al. (2004). Specific primers AC (5'-CTG TTT CCC GCA AGG GAC-3 ') and DI (5'-GCG CCC CAT TGC TGG GTT-3') were used, which amplify a specific region of the 16S rRNA gene in $G$. diazotrophicus. The second pair of primers used was RB (5'-AGA GTT TGA TYM TGG CTC AG-3') and RM (5'-GGA CTA CCA GGG TAT CTA ATC C-3'), which amplify a region of the 16S rRNA gene in all Bacteria. Reactions of $20 \mu \mathrm{L}$ were prepared, using a concentration of $0.5 \mu \mathrm{M}$ for each primer and $1 \mu \mathrm{L}$ of the sample. The PCR conditions were $3 \mathrm{~min}$ at $95^{\circ} \mathrm{C}$, followed by 30 cycles of $95^{\circ} \mathrm{C}$ for $30 \mathrm{~s}, 58^{\circ} \mathrm{C}$ for $30 \mathrm{~s}$ and $72^{\circ} \mathrm{C}$ for $45 \mathrm{~s}$, with a final extension at $72{ }^{\circ} \mathrm{C}$ for $5 \mathrm{~min}$. PCR products were visualized on a $1.5 \%$ agarose gel stained with ethidium bromide.

\section{Phosphate and zinc solubilization assay}

To evaluate the phosphates solubilization ability, the medium developed by the National Botanical Research Institute's Phosphate (NBRIP) was used, using glucose as a carbon source. Incubation was 
performed at $30{ }^{\circ} \mathrm{C}$ for 3 days and then measurements were made of the solubilization zone to establish the solubilization rates of each culture (Singh et al., 2015). For the zinc solubilization test, the NBRIP medium was modified by adding $\mathrm{ZnO}(0.12 \%)$ instead of TCP (Saravanan et al., 2007). The evaluation of the solubilizing ability was carried out in the same way as for phosphates.

\section{Phytohormones production}

The production of IAA was evaluated using LGIP medium with tryptophan $(0.5 \mathrm{~g} / \mathrm{L})$. Incubation was performed for 48 hours at 30 ${ }^{\circ} \mathrm{C}$. The cultures were centrifuged at 10,000 RPM for $5 \mathrm{~min}$. $250 \mu \mathrm{L}$ of culture supernatant was mixed with $500 \mu \mathrm{L}$ of Salkowski reagent, keeping it in darkness for $30 \mathrm{~min}$. The analysis was made in a UviLine 9400 UVIVIS spectrophotometer (Schott) at $530 \mathrm{~nm}$. The uninoculated medium was used as control and a calibration curve was made with IAA (Sigma) (Grobelak et al., 2015).

\section{Salinity tolerance test}

Peptone broth was prepared with $\mathrm{NaCl}$ concentrations of $0,0.25,0.5$ and $1 \%$. Incubation was performed for 3 days at $\mathbf{3 0}$ ${ }^{\circ} \mathrm{C}$ and the presence of microbial growth was observed by measuring absorbance at $600 \mathrm{~nm}$ (Tejera et al., 2003).

\section{Antifungal activity}

Bacterial cultures were cultivated on plates with PDA. Four equidistant lines were inoculated at the ends of the plate and incubated for 48 hours at $30{ }^{\circ} \mathrm{C}$. Fusarium sp., Alternaria sp., Roselinia sp., Lasiodiplodia sp., and Sclerotinia sp. 5-day cultures were taken and inoculated in the center of the plates. It was incubated at 25 ${ }^{\circ} \mathrm{C}$ until the development of the fungi in the control plate reached the bacterial inoculation zone. To determine the inhibition percentage, this formula was used: \% inhibition = $((\mathrm{RT}-\mathrm{RC}) / \mathrm{RT}) \times 100$; where $\mathrm{RT}$ :
Radio Control of the fungus; RC: Radio of the fungus faced with the bacteria (Mohamad et al., 2018).

\section{Plant inoculation}

Bacteria were cultivated on $2 \%$ sucrose potato medium and then eight bacterial treatments were established: T1: LASFB 1740, T2: LASFB 1573, T3: LASFB 1574, T4: LASFBC 461, T5: LASFBC 1911, T6: LASFB 1740 + LASFB 1643 + LASFB 002, T7: LASFB 1573 + LASFBP 086 + LASFB 009, T8: LASFBC 461 + LASFB 1643 + LASFBP 086. Kosakonia sp. LASFB 1643, Klebsiella sp. LASFBP 086, Enterobacter sp. LASFB 009 and Bacillus sp. LASFB 002, belong to laboratory bacterial collection. The control treatments were established considering one with an uninoculated medium and the second with water. $1 \mathrm{ml}$ of each 0.2 OD600 suspensions or control was added to $30 \mathrm{ml}$ of $1 / 10 \mathrm{MS}$ solution. In vitro sugarcane seedlings variety Mex73-523 were inoculated in the pre-acclimation stage. Seedlings were immersed in respective treatment for 30 minutes. The seedlings were transferred to trays filled with peat and were evaluated after 60 days.

\section{Results and discussion}

Phenotypic and molecular characterization

Five bacteria with the phenotypic characterristics described for $G$. diazotrophicus were isolated: LASFB 1573, LASFB 1574, LASFB 1740, LASFBC 461 and LASFBC 1911, observing development of orange colonies in LGIP medium (Figure 1), and brownishcolored colonies in SPA. The results of the biochemical tests were also the same as those reported for the reference strain (Gillis et al., 1989; Madhaiyan et al., 2004), and the presence of a specific amplification product of approximately 445 bp was observed when Multiplex PCR was carried out that confirm de molecular identification.
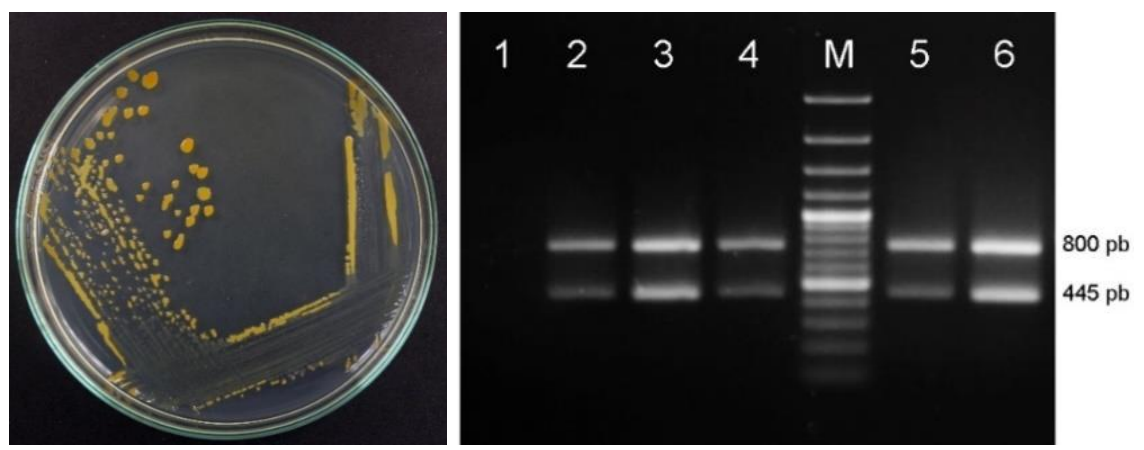

Figure 1. Right. Isolate LASFB 1740 in LGIP medium. Left. Multiplex PCR for G. diazotrophicus identification. Lane 1. PCR control, 2. LASFB 1573, 3. LASFB 1574, 4. LASFB 1740, 5. LASFBC 461, 6. LASFBC 1911, M. Ladder marker. 
Table 1

Results of physiological tests of $G$. diazotrophicus isolated from sugarcane

\begin{tabular}{|c|c|c|c|c|c|c|c|}
\hline Bacteria code & $\begin{array}{c}\text { Phosphate } \\
\text { solubilization } \\
\text { index }\end{array}$ & $\begin{array}{l}\text { Zinc Solubilization } \\
\text { index }\end{array}$ & $\begin{array}{l}\text { Indole Acetic Acid } \\
\text { production }(\mu \mathrm{g} / \mathrm{ml})\end{array}$ & \multicolumn{4}{|c|}{$\begin{array}{c}\text { Saline Stress Tolerance } \\
(\mathrm{NaCl})\end{array}$} \\
\hline LASFB 1573 & 2.22 & 4.27 & 65.71 & + & + & + & + \\
\hline LASFB 1740 & 2.73 & 3.83 & 71.47 & + & + & + & + \\
\hline LASFBC 461 & 1.71 & 8.00 & 34.44 & + & + & + & + \\
\hline LASFBC 1911 & 2.30 & 5.80 & 21.50 & + & + & + & + \\
\hline
\end{tabular}

+: Positive growth; -: Negative growth.

The bacteria were isolated from leaf and stem samples, and no isolation at the root level was attained that demonstrate the skill of this bacterium to move to different plant tissues, which has been observed in other vegetables such as corn (Tian et al., 2009) and other crops considered subtropical (Madhaiyan et al., 2004). However, it was also noted a low number of isolates, which could be related to an absence of this bacteria in the tissues of plants, or perhaps to a low cellular concentration of the same due to the high fertilization rates used on the field. Some authors have described that there is an inverse relationship between fertilization and the presence of nitrogenfixing bacteria, demonstrating that in the presence of nitrogen fertilizers the population of $G$. diazotrophicus is considerably reduced (Muthukumarasamy et al., 2006; Rodríguez-Andrade et al., 2015). There is the possibility that the varieties evaluated are not fully compatible with the bacteria. A study in Cuba conducted by Rojas et al. (2012), showed that from 18 varieties of sugarcane, it was only possible to isolate the bacteria in 13 of them (Rojas et al., 2012), and it was not possible to isolate them from sugarcane in a study carried out in Uruguay (Taulé et al., 2012). The analysis of varieties was not considered in this study.

\section{Plant growth promotion activity}

Isolated G. diazotrophicus have a moderate ability to solubilize phosphates, with an index of up to 2.73 . Their presence allowed the plants access to this important phosphate source and improved their growth (Delaporte-Quintana et al., 2017). The solubilization of these phosphates has been associated with the production of gluconic acids derived from metabolism, which are excreted into the environment, favoring the availability of phosphates for the plant (Intorne et al., 2009).

The solubilization of zinc was higher than phosphate, observing an index of 9.83 for the isolate LASFB 1574. Equally, the solubilization of zinc is considered important, because in some cases this micronutrient is not available to be taken up by the plant. The results show that all the isolates were able to solubilize $\mathrm{ZnO}$ in proportions similar or slightly higher than what was reported by Saravanan et al. (2007), who also demonstrated that this bacterium solubilizes other sources of zinc (Saravanan et al., 2007). Intorne et al. (2009) in 2009 demonstrated that phosphate and zinc solubilization processes would be related to the same genes and Saravanan et al. (2007) proposed that this property could influence resistance to $M$. incognita infections in tomato plants. Regarding the capability to produce IAA, slightly variable values were observed between $21.5 \mu \mathrm{g} / \mathrm{ml}$ and $71.47 \mu \mathrm{g} / \mathrm{ml}$. These isolates have a considerable high IAA level production, compared to reported before (Madhaiyan et al., 2004). Saline Stress Tolerance was evaluated, showing that the isolates were able to develop up to a concentration of $1 \% \mathrm{NaCl}$ (Table 1). The isolates showed tolerance to different $\mathrm{NaCl}$ concentrations, which allows us to evaluate the microbial ability to survive in hostile environments, as well as the possibility of helping the plant to have better development in the same conditions, as it has been demonstrated in other studies done with different bacteria (Bhardwaj et al., 2014). This salt stress resistance could be related to the production of $A C C$ deaminase or exopolysaccharides (Khamwan et al., 2018). However, it was observed that the increase in $\mathrm{NaCl}$ concentration affects the physiological properties of these bacteria (Tejera et al., 2003).

\section{Antagonistic activity}

G. diazotrophicus antagonistic tests have been carried out before on fungi such as Colletotrichum, Fusarium, and Helminthosporium (Muthukumarasamy et al., 2000; Chawla et al., 2014). G. diazotrophicus isolated in this study showed activity against $A$ lternaria sp., Roselinia sp., Lasiodiplodia sp., or Sclerotinia sp.; however, the inhibition was lower to Sclerotinia sp., even nil on LASFB 1573 and LASFB 1740. The isolates showed a percentage of inhibition like the $73.62 \%$ reported by 
Logeshwarn et al. (2011), against Fusarium oxysporum, suggesting that different species of the genus Fusarium may be inhibited by this bacterial action. These results are similar with observed on some genre Bacillus strains that have shown inhibition results for Sclerotinium up to 81.9\% (Kamal et al., 2015), 58.9\% for Lasiodiplodia (Chukeatirote et al., 2018), and $62.9 \%$ for Alternaria (Sharma and Sharma, 2008). Some authors have proposed the synthesis of gluconic acids as antifungal compounds that diffuse in the culture medium (Bertini et al., 2014), and bacteria could also be controlled by the production of gluconacin that has shown a growth inhibition against pathogenic plant-bacteria (Oliveira et al., 2018). In contrast, others have evaluated the production of volatile compounds that would have a similar effect (Meena et al., 2017).

\section{Plant inoculation test}

The inoculation experiments carried out with the bacterial isolates show that they are all capable of improving the plant development of sugarcane plants. The inoculation of treatments T5 and the mixture of T7 were the treatments with a higher impact on plant growth parameters. The increase in total dry weight was up to $92 \%$ and $89 \%$ for T5 and T7, respectively. These treatments also have a satisfactory influence on root development, with $78 \%$ and $53 \%$ of fresh weight root over the control (Table 3).

G. diazotrophicus has shown satisfactory results in sugarcane inoculation, increasing the levels of dry matter and production when it was inoculated with other endophytic bacteria, increasing by $21 \%$ and $18 \%$ for the diameter of stem and total dry matter, respectively (Schultz et al., 2017). In this study, those parameters increased by $9 \%$ and $92 \%$, respectively when plants were inoculated with LASFBC 1911. The increases obtained for LASFBC 1911 are also greater than reported by Muthukumarasamy et al. (2006) who obtained an increase of $45 \%$ for the fresh weight of roots and $35 \%$ for total fresh weight. The inoculation with $G$. diazotrophicus could also increase the antioxidative and osmoprotectant compounds that help plant development (Aguiar et al., 2018), that was not tested in this research.

However, co-inoculation with other endophytic or rhizospheric bacteria has offered more consistent results in almost all parameters evaluated, as observed with T7. This treatment considered the inoculation of three bacteria that could fix nitrogen, solubilize nutrients and/or produce IAA. Oliveira et al. (2002) also demonstrated than the co-inoculation with $G$. diazotrohpicus, $A$. amazonense, and Burkholderia sp. could increase plant development.

These results are explained according to a combination of properties of bacteria, and how this could give more complete support for plant development (dos Santos et al., 2017). The inoculation of the bacteria mixtures also evidences that there is not high specificity between these bacteria and the source plants. The bacteria different from $G$. diazotrophicus were isolated from avocado, pineapple, and sugarcane. With these results, many inoculation tests could be delivered employing bacteria from different sources in a high variety of crops.

Table 2

Growth inhibition of phytopathogenic fungi by isolates of $G$. diazotrophicus

\begin{tabular}{|c|c|c|c|c|c|}
\hline Bacteria & Fusarium sp. & Alternaria sp. & Roselinia sp. & Lasiodiplodia sp. & Sclerotinia sp. \\
\hline LASFB 1573 & $61 \%$ & $55 \%$ & $32 \%$ & $31 \%$ & $0 \%$ \\
\hline LASFB 1740 & $67 \%$ & $57 \%$ & $26 \%$ & $35 \%$ & $0 \%$ \\
\hline LASFBC 1911 & $69 \%$ & $54 \%$ & $30 \%$ & $40 \%$ & $17 \%$ \\
\hline
\end{tabular}

Table 3

Effect of inoculation of $G$. diazotrophicus on physiological parameters in sugarcane variety Mex 73-523

\begin{tabular}{|c|c|c|c|c|c|c|c|c|c|c|}
\hline Bacteria & $\begin{array}{l}\text { Plant high } \\
\text { (cm) }\end{array}$ & $\begin{array}{l}\text { Diameter } \\
\quad(\mathrm{cm})\end{array}$ & $\begin{array}{l}\text { Foliar } \\
\text { area } \\
\left(\mathrm{cm}^{2}\right) \\
\end{array}$ & $\begin{array}{c}\text { Aerial fresh } \\
\text { weight } \\
\text { (g) }\end{array}$ & $\begin{array}{l}\text { Aerial dry } \\
\text { weight } \\
\text { (g) }\end{array}$ & $\begin{array}{l}\text { Roots } \\
\text { Long } \\
(\mathrm{cm}) \\
\end{array}$ & $\begin{array}{l}\text { Fresh } \\
\text { Weight } \\
\text { root }(g)\end{array}$ & $\begin{array}{c}\text { Dry } \\
\text { Weight } \\
\text { root }(g)\end{array}$ & $\begin{array}{c}\text { Total } \\
\text { fresh } \\
\text { weight }(\mathrm{g})\end{array}$ & $\begin{array}{c}\text { Total } \\
\text { dry } \\
\text { weight }(g)\end{array}$ \\
\hline Control 1 & $30.44 \mathrm{a}$ & $3.3 \mathrm{ab}$ & $22.88 a$ & $0.7174 a$ & $0.0946 a$ & $15.25 \mathrm{abc}$ & $1.0203 \mathrm{a}$ & $0.1095 a$ & $1.7397 \mathrm{a}$ & $0.2042 a$ \\
\hline Control 2 & $32.71 \mathrm{ab}$ & $3.3 \mathrm{ab}$ & $25.01 \mathrm{ab}$ & $0.7999 a b$ & $0.1073 a$ & $16.62 \mathrm{abc}$ & $1.1368 \mathrm{ab}$ & $0.1117 a b$ & $1.9368 \mathrm{ab}$ & $0.2190 a b$ \\
\hline T1 & $34.43 \mathrm{abc}$ & $3.1 \mathrm{ab}$ & $29.91 \mathrm{abc}$ & $0.8858 a b$ & $0.1442 a b$ & $13.84 \mathrm{a}$ & $1.3530 \mathrm{abc}$ & $0.1332 \mathrm{abc}$ & $2.2388 \mathrm{abc}$ & $0.2773 \mathrm{abc}$ \\
\hline T2 & $37.43 \mathrm{bcd}$ & $3.1 \mathrm{a}$ & $35.37 \mathrm{c}$ & $1.0675 \mathrm{bc}$ & $0.1526 a b$ & $14.50 \mathrm{ab}$ & $1.5773 \mathrm{~cd}$ & $0.1634 \mathrm{abc}$ & $2.6449 \mathrm{~cd}$ & $0.3160 \mathrm{abc}$ \\
\hline T3 & $37.95 \mathrm{bcd}$ & $3.2 \mathrm{ab}$ & $34.81 \mathrm{c}$ & $1.0265 \mathrm{bc}$ & $0.1695 a b$ & $15.97 \mathrm{abc}$ & $1.4285 \mathrm{bc}$ & 0.1795 bc & $2.4550 \mathrm{bcd}$ & $0.3490 \mathrm{bc}$ \\
\hline T4 & $36.21 \mathrm{bcd}$ & $3.2 \mathrm{ab}$ & $30.56 \mathrm{bc}$ & $0.9564 \mathrm{abc}$ & $0.2276 \mathrm{~b}$ & $15.64 \mathrm{abc}$ & $1.3636 \mathrm{abc}$ & $0.1371 \mathrm{abc}$ & $2.3197 \mathrm{abc}$ & $0.3647 \mathrm{c}$ \\
\hline T5 & $39.18 \mathrm{~cd}$ & $3.6 \mathrm{~b}$ & $32.41 \mathrm{c}$ & $1.2065 \mathrm{c}$ & $0.1968 a b$ & $16.94 \mathrm{bc}$ & $1.8155 \mathrm{~d}$ & $0.1963 \mathrm{c}$ & $3.0221 d$ & $0.3930 \mathrm{c}$ \\
\hline T6 & $39.55 \mathrm{~cd}$ & $3.4 \mathrm{ab}$ & $30.40 \mathrm{bc}$ & $1.0618 \mathrm{bc}$ & $0.1637 a b$ & $17.20 \mathrm{c}$ & $1.4837 \mathrm{bcd}$ & $0.1786 \mathrm{abc}$ & $2.5455 \mathrm{bcd}$ & $0.3424 \mathrm{abc}$ \\
\hline T7 & $41.16 \mathrm{~d}$ & $3.5 \mathrm{ab}$ & $35.01 \mathrm{c}$ & $1.2067 \mathrm{c}$ & $0.1857 a b$ & $16.40 \mathrm{abc}$ & $1.5562 \mathrm{~cd}$ & $0.2010 \mathrm{c}$ & $2.7629 \mathrm{~cd}$ & $0.3868 \mathrm{c}$ \\
\hline T8 & $38.43 \mathrm{~cd}$ & $3.3 \mathrm{ab}$ & $29.49 \mathrm{abc}$ & $1.0257 \mathrm{bc}$ & $0.1749 a b$ & $16.55 \mathrm{bc}$ & $1.4996 \mathrm{bcd}$ & $0.1763 \mathrm{abc}$ & $2.5252 \mathrm{bcd}$ & $0.3512 \mathrm{bc}$ \\
\hline
\end{tabular}




\section{Conclusions}

The bacterium $G$. diazotrophicus is present in vegetal tissues of sugarcane cultivated in the northern zone of Peru. The isolated and characterized native bacteria show a physiological profile that allows them to be classified as plant growth-promoting bacteria, being possible to infer a beneficial effect in subsequent inoculation field tests.

\section{Acknowledgments}

The current project was made possible by the support of Innovate Peru Contract No 142-PNICPPIAP-2015, as part of the Ministry of Production of Peru.

\section{References}

Aguiar, N.O.; Olivares, F.L.; Novotny, E.H.; and Canellas, L.P. 2018. Changes in metabolic profiling of sugarcane leaves induced by endophytic diazotrophic bacteria and humic acids. PeerJ 6: e5445.

Baldani, J.I.; Reis, V.M.; Videira, S.S.; Boddey, L.H.; Baldani, V.L.D. 2014. The art of isolating nitrogenfixing bacteria from non-leguminous plants using $\mathrm{N}$ free semi-solid media: a practical guide for microbiologists. Plant and Soil 384: 413-431.

Bertini, E.V.; Nieto Peñalver, C.G.; Leguina, A.C.; Irazusta, V.P.; De Figueroa, L.I.C. 2014. Gluconacetobacter diazotrophicus PAL5 possesses an active quorum sensing regulatory system. Antonie van Leeuwenhoek 106: 497-506.

Bhardwaj, D.; Ansari, M.; Sahoo, R.; Tuteja, N. 2014. Biofertilizers function as key player in sustainable agriculture by improving soil fertility, plant tolerance and crop productivity. Microbial Cell Factories 13(1): 66.

Bishnoi, U. 2015 PGPR Interaction: An Ecofriendly Approach Promoting the Sustainable Agriculture System. Advances in Botanical Research 75: 81-113.

Botta, A.L.; Santacecilia, A.; Ercole, C.; Cacchio, P.; Del Gallo, M. 2013. In vitro and in vivo inoculation of four endophytic bacteria on Lycopersicon esculentum. New Biotechnology 30(6): 666-674.

Bouraoui, F.; Grizzetti, B. 2013. Modelling mitigation options to reduce diffuse nitrogen water pollution from agriculture. Science of the Total Environment 468-469: 1267-1277.

Brader, G.; Compant, S.; Mitter, B.; Trognitz, F.; Sessitsch, A. 2014. Metabolic potential of endophytic bacteria. Current Opinion in Biotechnology 27: 30 37.

Chawla, N.; Phour, M.; Suneja, S.; Sangwaan, S.; Goyal, S. 2014. Gluconacetobacter diazotrophicus: An overview. Research in Environment and Life Sciences 7(1): 1-10.

Chukeatirote, E.; Phueaouan, T.; Piwkam, A. 2018. Screening of rhizosphere soil bacteria for biocontrol of Lasiodiplodia theobromae. Agriculture and Natural Resources 52(4): 325-329.

Delaporte-Quintana, P.; Grillo-Puertas, M.; Lovaisa, N.C.; Teixeira, K.R.; Rapisarda, V.A.; Pedraza, R.O. 2017. Contribution of Gluconacetobacter diazotrophicus to phosphorus nutrition in strawberry plants. Plant and Soil 419(1-2): 335-347.

Gaiero, J.R.; McCall, C.A.; Thompson, K.A.; Day, N.J.; Best, A.S.; Dunfield, K.E. 2013. Inside the root microbiome: Bacterial root endophytes and plant growth promotion. American Journal of Botany 100(9): 1738-1750.

Gillis, M.; Kersters, K.; Hoste, B.; Janssens, D.; Kroppenstedt, R.M.; Stephan, M.P., Teixeira, K.R.D.S.; Döbereiner, J.; De Ley, J. 1989. Acetobacter diazotrophicus sp. nov., a NitrogenFixing Acetic Acid Bacterium Associated with
Sugarcane. International Journal of Systematic Bacteriology 39(3): 361-364.

Grobelak, A.; Napora, A.; Kacprzak, M. 2015. Using plant growth-promoting rhizobacteria (PGPR) to improve plant growth. Ecological Engineering 84: 22-28.

Hernández-Escareño, J.J.; Gabriel Morales, P.; Farías Rodríguez, R.; Sánchez-Yáñez, J.M. 2015. Inoculation of Burkholderia cepacia and Gluconacetobacter diazotrophicus on phenotype and biomass of Triticum aestivum var. Nana-F2007 at $50 \%$ of nitrogen fertilizer. Scientia Agropecuaria 6(1): 7-16.

Intorne, A.C.; De Oliveira, M.V.V.; Lima, M.L.; Da Silva, J.F.; Olivares, F.L.; De Souza Filho, G.A. 2009. Identification and characterization of Gluconacetobacter diazotrophicus mutants defective in the solubilization of phosphorus and zinc. Archives of Microbiology 191: 477-483.

Jha, B.; Thakur, M.C.; Gontia, I.; Albrecht, V.; Stoffels, M.; Schmid, M.; Hartmann, A. 2009. Isolation, partial identification and application of diazotrophic rhizobacteria from traditional Indian rice cultivars. European Journal of Soil Biology 45: 62-72.

Kamal, M.M.; Lindbeck, K.D.; Savocchia, S.; Ash, G.J. 2015. Biological control of Sclerotinia stem rot of canola using antagonistic bacteria. Plant Pathology 64(6): 1375-1384.

Khamwan, S.; Boonlue, S.; Riddech, N.; Jogloy, S.; Mongkolthanaruk, W. 2018. Characterization of endophytic bacteria and their response to plant growth promotion in Helianthus tuberosus L. Biocatalysis and Agricultural Biotechnology 13: 153159.

Khan, A.L.; Waqas, M.; Kang, S.M.; Al-Harrasi, A.; Hussain, J.; Al-Rawahi, A.; Al-Khiziri, S.; Ullah, I.; Ali, L.; Jung, H.Y.; Lee, I.J. 2014. Bacterial endophyte Sphingomonas sp. LK11 produces gibberellins and IAA and promotes tomato plant growth. Journal of Microbiology 52(8): 689-695.

Logeshwarn, P.; Thangaraju, M.; Rajasundari, K. 2011. Antagonistic potential of Gluconacetobacter diazotrophicus against Fusarium oxysporum in sweet potato (Ipomea batatus). Archives of Phytopathology and Plant Protection 44(3): 216-223.

Luna, M.F.; Aprea, J.; Crespo, J.M.; Boiardi, J.L. 2012. Colonization and yield promotion of tomato by Gluconacetobacter diazotrophicus. Applied Soil Ecology 61: 225-229.

Madhaiyan, M.; Saravanan, V.S.; Jovi, D.B.S.S.; Lee, H.; Thenmozhi, R.; Hari, K.; Sa, T. 2004. Occurrence of Gluconacetobacter diazotrophicus in tropical and subtropical plants of Western Ghats, India. Microbiological Research 159: 233-243.

Meena, V.S.; Meena, S.K.; Verma, J.P.; Kumar, A.; Aeron, A.; Mishra, P.K.; Bisht, J.K.; Pattanayak, A.; Naveed, M.; Dotaniya, M.L. 2017. Plant beneficial rhizospheric microorganism (PBRM) strategies to improve nutrients use efficiency: A review. Ecological Engineering 107: 8-32.

Mehnaz, S.; Weselowski, B.; Lazarovits, G. 2006. Isolation and identification of Gluconacetobacter azotocaptans from corn rhizosphere. Systematic and Applied Microbiology 29: 496-501.

Mohamad, O.A.A.; Li, L.; Ma, J.B.; Hatab, S.; Xu, L.; Guo, J.W.; Rasulov, B.A.; Liu, Y.H.; Hedlund, B.P.; Li, W.J. 2018. Evaluation of the antimicrobial activity of endophytic bacterial populations from Chinese traditional medicinal plant licorice and characterization of the bioactive secondary metabolites produced by Bacillus atrophaeus Against Verticillium dahliae. Frontiers in Microbiology 9(May): 1-14.

Muthukumarasamy, R.; Cleenwerck, I.; Revathi, G.; Vadivelu, M.; Janssens, D.; Hoste, B.; Ui, K.; Park, K.; Young, C.; Sa, T.; Caballero-mellado, J. 2005. Natural association of Gluconacetobacter diazotrophicus and diazotrophic Acetobacter peroxydans with wetland rice. Sistematic and Applied Microbiology 28: 277-286. 
Muthukumarasamy, R.; Govindarajan, M.; Vadivelu, M.; Revathi, G. 2006. $\mathrm{N}$-fertilizer saving by the inoculation of Gluconacetobacter diazotrophicus and Herbaspirillum sp. in micropropagated sugarcane plants. Microbiological Research 161: 238-245.

Muthukumarasamy, R.; Revathi, G.; Vadivelu, M. 2000. Antagonistic potential of N2-fixing Acetobacter diazotrophicus against Colletotrichum falcatum Went., a causal organism of red-rot of sugarcane. Current Science 78(9): 1063-1065.

Oliveira, A.L.M.; Stoffels, M.; Schmid, M.; Reis, V.M.; Baldani, J.I.; Hartmann, A. 2009. Colonization of sugarcane plantlets by mixed inoculations with diazotrophic bacteria. European Journal of Soil Biology 45(1): 106-113.

Oliveira, A.L.M.; Urquiaga, S.; Döbereiner, J.; Baldani, J.I. 2002. The effect of inoculating endophytic N2fixing bacteria on micropropagated sugarcane plants. Plant and Soil 242: 205-215.

Oliveira, M.M.; Ramos, E.T.A.; Drechsel, M.M.; Vidal, M.S.; Schwab, S.; Baldani, J.I. 2018. Gluconacin from Gluconacetobacter diazotrophicus PAL5 is an active bacteriocin against phytopathogenic and beneficial sugarcane bacteria. Journal of Applied Microbiology 125(6): 1812-1826.

Rivas, R.; Velzquez, V.; Valverde, A.; Mateos, P.F.; Martnez-Molina, E. 2001. A two primers random amplified polymorphic DNA procedure to obtain polymerase chain reaction fingerprints of bacterial species. Electrophoresis 22: 1086-1089.

Rodríguez-Andrade, O.; Fuentes-Ramírez, L.E.; MoralesGarcía, Y.E.; Molina-Romero, D.; Bustillos-Cristales, M.R.; Martínez-Contreras, R.D.; Muñoz-Rojas, J. 2015. The decrease in the population of Gluconacetobacter diazotrophicus in sugarcane after nitrogen fertilization is related to plant physiology in split root experiments. Revista Argentina de Microbiología 47(4): 335-343.

Rojas, M.; Manzano, J.; Heydrich, M. 2012. Aislamiento e identificación de Gluconacetobacter diazotrophicus a partir de variedades de caña de azúcar cultivadas en Cuba. Revista Cubana de Ciencias Biológicas 1(1): 29-33.

Dos Santos, S.; da Silva Ribeiro, F.; Sousa da Fonseca, C.; Pereira, W.; Santos, L.A.; Reis, V.M. 2017. Development and nitrate reductase activity of sugarcane inoculated with five diazotrophic strains. Archives of Microbiology 199(6): 863-873.

Santoyo, G.; Moreno-Hagelsieb, G.; Orozco-Mosqueda, M. C.; Glick, B.R. 2016. Plant Growth-Promoting Bacterial Endophytes. Microbiological Research 183: 92-99.
Saravanan, V.S.; Kalaiarasan, P.; Madhaiyan, M.; Thangaraju, M. 2007. Solubilization of insoluble zinc compounds by Gluconacetobacter diazotrophicus and the detrimental action of zinc ion ( $\mathrm{Zn2+}$ ) and zinc chelates on root knot nematode Meloidogyne incognita. Letters in Applied Microbiology 44: 235 241.

Saravanan, V.S.; Madhaiyan, M.; Thangaraju, M. 2007. Solubilization of zinc compounds by the diazotrophic, plant growth promoting bacterium Gluconacetobacter diazotrophicus. Chemosphere 66: 1794-1798.

Schultz, N.; Pereira, W.; de Albuquerque Silva, P.; Baldani, J.I.; Boddey, R.M.; Alves, B.J.R.; Urquiaga, S.; Reis, V.M. 2017. Yield of sugarcane varieties and their sugar quality grown in different soil types and inoculated with a diazotrophic bacteria consortium. Plant Production Science (October): 1-9.

Sharma, N.; Sharma, S. 2008. Control of foliar diseases of mustard by Bacillus from reclaimed soil. Microbiological Research 163: 408-413.

Singh, R.P.; Jha, P.; Jha, P.N. 2015. The plant-growthpromoting bacterium Klebsiella sp. SBP-8 confers induced systemic tolerance in wheat (Triticum aestivum) under salt stress. Journal of Plant Physiology 184: 57-67.

De Souza, R.; Ambrosini, A.; Passaglia, L.M.P. 2015 Plant growth-promoting bacteria as inoculants in agricultural soils. Genetics and Molecular Biology 38(4): 401-419.

Tabassum, B.; Khan, A.; Tariq, M.; Ramzan, M.; Iqbal Khan, M.S.; Shahid, N.; Aaliya, K. 2017. Bottlenecks in commercialisation and future prospects of PGPR. Applied Soil Ecology 121: 102-117.

Taulé, C.; Mareque, C.; Barlocco, C.; Hackembruch, F.; Reis, V.M.; Sicardi, M.; Battistoni, F. 2012. The contribution of nitrogen fixation to sugarcane (Saccharum officinarum L.), and the identification and characterization of part of the associated diazotrophic bacterial community. Plant and Soil 356: 35-49.

Tejera, N.A.; Ortega, E.; González-López, J.; Lluch, C. 2003. Effect of some abiotic factors on the biological activity of Gluconacetobacter diazotrophicus. Journal of Applied Microbiology 95: 528-535.

Tian, G.; Pauls, P.; Dong, Z.; Reid, L.M.; Tian, L. 2009. Colonization of the nitrogen-fixing bacterium Gluconacetobacter diazotrophicus in a large number of Canadian corn plants. Canadian Journal of Plant Science 89(6): 1009-1016.

Vejan, P.; Abdullah, R.; Khadiran, T.; Ismail, S.; Nasrulhaq Boyce, A. 2016. Role of plant growth promoting rhizobacteria in agricultural sustainability - A review. Molecules 21(573): 1-17. 